\title{
Estimation of endogenous contribution and urinary excretion of purine derivatives from the total digestible nutrient intake in Nellore heifers
}

\author{
Jercyane Maria da Silva Braga ${ }^{2}$, Rilene Ferreira Diniz Valadares ${ }^{3}$, Samantha Gusmão \\ Pellizzoni ${ }^{2}$, Sebastião de Campos Valadares Filho ${ }^{4}$, Luciana Louzada Prates ${ }^{2}$, Luiz Fernando \\ Costa e Silva ${ }^{5}$
}

\footnotetext{
${ }^{1}$ Financed by CNPq and INCT - CA.

${ }^{2}$ Programa de Pós-graduação em Medicina Veterinária - UFV.

${ }^{3}$ Departamento de Medicina Veterinária - UFV.

${ }^{4}$ Departamento de Zootecnia - UFV.

${ }^{5}$ Programa de Pós-graduação em Zootecnia - UFV.
}

\begin{abstract}
The objectives of this experiment were to estimate the endogenous excretion of purine derivatives (PD), the intake and digestibility of nutrients, the urinary excretion of PD from the intake of total digestible nutrients (TDN) and digestible organic matter (DOM) in Nellore heifers. Eight heifers, $267 \pm 17 \mathrm{~kg}$ body weight (BW), were assigned to two $4 \times 4$ latin squares. The planned treatments were four dry matter intake (DMI) levels: 10, 14, 18 and $22 \mathrm{~g} / \mathrm{kg} \mathrm{BW}$. The diet contained $70 \%$ corn silage and $30 \%$ concentrate. The endogenous losses were obtained by regression between excretion of PD (mmol/BW $\left.{ }^{0.75}\right)$ and DMI (g/BW $\left.{ }^{0.75}\right)$. When PD excretion $(\mathrm{mmol} / \mathrm{d})$ was related to the intake of DOM and TDN (kg/d), the following equations were obtained: $\hat{\mathrm{Y}}_{\mathrm{PD}}=32.98+21.94 * \mathrm{DOM}$ and $\hat{\mathrm{Y}}_{\mathrm{PD}}=32.47+20.40 * \mathrm{TDN}$, respectively. The excretion of $\mathrm{PD}(\mathrm{mmol} / \mathrm{d})$ was a function of DMI $(\mathrm{kg} / \mathrm{d}): \hat{\mathrm{Y}}=0.605+0.014 \mathrm{x}\left(\mathrm{r}^{2}=0.46\right)$, and $0.60 \mathrm{mmol} / \mathrm{BW}^{0.75}$ was the endogenous fraction of PD. The endogenous losses of PD and nitrogen compounds obtained when the animals were fasted for $5 \mathrm{~d}$, with free access to water, were $0.332 \mathrm{mmol} / \mathrm{BW}^{0.75}$ and $0.384 \mathrm{gN} / \mathrm{BW}^{0.75}$, respectively. The net protein requirement for maintenance was estimated at $2.4 \mathrm{~g} / \mathrm{BW}^{0.75}$. Creatinine excretion is not affected by feed restriction.
\end{abstract}

Key Words: cattle, endogenous excretion, microbial protein

\section{Introduction}

The quantification of microbial protein production has been an important area of study in the nutrition of ruminants, once it is incorporated in all the current systems of protein evaluation used in different countries (Broderick \& Merchen, 1992).

The need for the development of non-invasive techniques in animal testing has favored the utilization of the excretion of purine derivatives (PD) in the urine for the determination of microbial protein production; however, considering that endogenous losses are subtracted from the total excretion of purine derivatives to quantify the production of microbial protein, one can observe that inadequate values may result in under- or overestimated microbial production (Susmel et al., 1994).

Although, at first, the urinary excretion of PD can be utilized as an identifier of the microbial protein synthesis, some factors utilized in the model which affect the excretion of PD are not yet completely elucidated. Among them are the purine $\mathrm{N}$ :total $\mathrm{N}$ ratio $(\mathrm{PN} / \mathrm{TN})$ in the ruminal microorganism, the recovery of absorbed purines and the excretion of purine derivatives of endogenous origin (Verbic et al., 1990; Chen \& Gomes, 1992; Orellana Boero et al., 2001).

The endogenous excretion represents an important parameter in the modeling of excretion of PD (Chen \& Orskov, 2003; Gonzalez-Ronquillo et al., 2003); however, it is of hard quantification in surgically intact animals (Fujihara et al., 1987), due to technical limitations to eliminate the contribution of ruminal microorganisms under physiological conditions in ruminants (Chen et al., 1990).

To estimate the endogenous fraction of the PD, the utilization of the intercept of the linear regression between the excretion of purine derivatives in the urine obtained with several intake levels is not an appropriate method for sheep (Chen et al., 1990), because the relation between excretion of PD and the absorption of purines is not linear. However, in cattle, this relation is linear (Chen \& Gomes, 1992), allowing the application of this evaluation method.

Thus, for the present study, eight heifers of the Nellore breed were subjected to fast or fed diets supplied from maintenance to voluntary intake, aiming to estimate the endogenous excretion of PD and to develop equations 
to estimate the urinary excretion of PD from the energy intake.

\section{Material and Methods}

The experiment was conducted in the Laboratório de Animais and in the Laboratório de Nutrição de Ruminantes of the Departamento de Zootecnia of the Centro de Ciências Agrárias of Universidade Federal de Viçosa.

Eight Nellore heifers with initial average weight of $267 \pm 17 \mathrm{~kg}$ were kept in feedlot at the Laboratory of Animals (DZO/UFV).

The diets, which were constituted of corn silage and concentrates at the ratios of 70 and $30 \%(\% \mathrm{DM})$, respectively, were supplied at levels 10,14, 18 and $22 \mathrm{~g} / \mathrm{kg}$ of body weight (BW), composing the experimental treatments. Diets were balanced to contain approximately $130 \mathrm{~g} \mathrm{CP} / \mathrm{kg}$ DM (Table 1).

Animals were distributed in two $4 \times 4$ Latin squares, balanced for residual effects. Each one of the experimental periods lasted 14 days; the first ten days were for animals to adapt to the levels of diet supply and from the 10th to the 14th days, samples of feed and leftovers, as well as total feces and urine, were collected.

The total diet was supplied twice daily (7:30 and 15:30 h) to the animals. Corn silage, concentrate and leftovers from each animal were quantified and sampled throughout the collection period. At the end of each period, composite samples of feed and leftovers were obtained and conditioned in plastic bags, then stored at $-20{ }^{\circ} \mathrm{C}$ for further analyses.

The total collection of feces from each animal was conducted with 20 L buckets, where feces were placed after each spontaneous defecation. At the end of each 24-hour period, feces were weighed and homogenized, and aliquots of approximately $300 \mathrm{~g}$ were stored. The composite sample of feces from each animal per period accounted for $10 \%$ of the daily fecal excretion.

Table 1 - Chemical composition $(\mathrm{g} / \mathrm{kg})$ of corn silage, concentrate and experimental diet

\begin{tabular}{lccr}
\hline & Corn silage & Concentrate $^{1}$ & Diet \\
\hline Dry matter & 276.5 & 886.1 & 459.4 \\
Organic matter $^{2}$ & 942.7 & 937.4 & 941.1 \\
Crude protein $^{2}$ & 72.0 & 260.7 & 128.6 \\
Ether extract $^{2}$ & 26.5 & 34.7 & 29.0 \\
Neutral detergent fiber corrected $^{2}$ & 522.5 & 118.5 & 401.3 \\
for ash and protein $^{2}$ & & & \\
Non-fibrous carbohydrates $^{2}$ & 321.7 & 562.7 & 394.0 \\
\hline
\end{tabular}

${ }^{1}$ Proportion of ingredients in the concentrate $(\mathrm{g} / \mathrm{kg} \mathrm{DM})$ : corn meal: 683.1; soybean meal: 261.2; urea/ammonium sulphate: 22.1 ; and mineral matter: 33.6.

${ }^{2} \mathrm{~g} / \mathrm{kg}$ DM of the diet.
The total collection of urine from each animal was performed from the 11th to the 14th days, with the aid of two-way Folley probes no. 22, with $30 \mathrm{~mL}$ flask. On the free end of the probe, a polyethylene rose was adapted, through which the urine was conducted until plastic lidded containers, containing $200 \mathrm{~mL} \mathrm{H}_{2} \mathrm{SO}_{4}$ at $20 \%$ to keep the final urine $\mathrm{pH}$ below 3 . At the end of each 24 hours collection period, urine was weighed and homogenized, with subsequent collection of $10 \mathrm{~mL}$ samples, which were diluted with $40 \mathrm{~mL} 0.036 \mathrm{~N} \mathrm{H}_{2} \mathrm{SO}_{4}$ and $50 \mathrm{~mL}$ without dilution. At the end of each collection experiment, a composite sampling of urine was made based on the daily excretion of each animal. Diluted and concentrated samples were stored at $-20{ }^{\circ} \mathrm{C}$ for further analysis of allantoin, uric acid and creatinine.

In the samples of silages, concentrate and feces, laboratory analyses of dry matter (DM), organic matter $(\mathrm{OM})$, crude protein $(\mathrm{CP})$ and ether extract (EE) were performed according to techniques described by Silva \& Queiroz (2002), whereas the NDF contents were estimated according to recommendation by Mertens (2002). The corrections made for ash and protein contents (NDFap) were conducted according to Mertens (2002) and Licitra et al. (1996), respectively.

Analyses of allantoin in the urine were done by the collorimetric method, according to technique of Fujihara et al. (1987), described by Chen \& Gomes (1992). For determinations of creatinine and uric acid in the urine, commercial kits from Labtest Diagnóstica S.A. were used.

The total urinary excretion of purine derivatives (PD) was calculated by the sum of the excretions of allantoin and uric acid in the urine, expressed in $\mathrm{mmol} /$ day.

Endogenous losses were calculated through the intercept of the linear regression equation between the $\mathrm{PD}$ excretion $\left(\mathrm{mmol} / \mathrm{kgBW}^{0.75}\right)$ in function of $\mathrm{DM}$ intake $\left(\mathrm{g} / \mathrm{kgBW}^{0.75}\right)$.

The relation between TDN intake and digestible organic matter (DOM) with the excretion of purine derivatives (mmol/day) was evaluated by means of simple linear regression model.

Absorbed purines (AP) were estimated from the $\mathrm{PD}$ excretion according to the equation: $\mathrm{AP}=\left[\mathrm{PD}-\left(0.301 * \mathrm{BW}^{0.75}\right) / 0.80\right]$, in which 0.301 is the endogenous excretion and 0.80 stands for the recovery of absorbed purines (Barbosa et al., 2011). Microbial nitrogenous compounds (MN) were calculated from absorbed purines, utilizing the equation: $\mathrm{MN}=$ $(70 * \mathrm{AP}) / 0.93 * 0.137 * 1000$, in which 70 is the content in $\mathrm{mg} \mathrm{N}$ per mmol of purine, 0.93 is the true digestibility of purines and 0.137 is the average MN:totalN ratio obtained for rumen-isolated bacteria (Barbosa et al., 2011). 
Endogenous losses were also obtained after the end of the experimental period, when all the animals were subjected to the following feeding regimen: restriction to $1 \% \mathrm{BW}$ in $\mathrm{DM}$ on the first eight days, to $0.5 \% \mathrm{BW}$ from the ninth to the 11th days and fasting from the 12th to the 16th day, with free access to water. From the twelfth to the sixteenth days, total collection of urine was performed in each animal and samples were stored and analyzed for creatinine, uric acid and allantoin, as previously described. The endogenous excretion of purine derivatives was calculated by the sum of the excretions of allantoin and uric acid in the urine, expressed in $\mathrm{mmol} /$ day or $\mathrm{mmol} / \mathrm{kg} \mathrm{BW}{ }^{0.75}$, corresponding to the fourth and fifth days of fasting. The endogenous $\mathrm{N}$ was evaluated through the $\mathrm{N}$ found in the feces and urine on the fourth and fifth days of fasting. The creatinine excretion was evaluated during the five days of fasting.

The results were evaluated by means of variance analysis through PROC GLM of the software SAS (Statistical Analysis System, version 8). The model included effects of treatments, Latin square, animal housed in Latin square, period housed in Latin square and the interaction of Latin square and treatment. Linear, quadratic and cubic effects of the variables in relation to the variation in the DM intake observed were evaluated considering the DM intake observed as the independent variable. The linear regression models were also adjusted by means of PROC GLM of SAS, considering $\alpha=0.05$.

\section{Results and Discussion}

Increasing linear effect $(\mathrm{P}<0.05)$ was verified for the DM, OM, CP, EE, NDFap, NFC and TDN intakes, in function of the levels of DM intake in the diet, according to the experimental planning (Table 2).

The average DM intake values observed were 10.0; $13.9 ; 17.5$ and $21.0 \mathrm{~g} / \mathrm{kg} \mathrm{BW}$, similarly to those planned for generating a wide range of microbial $\mathrm{CP}$ ruminal synthesis and, consequently, greater duodenal flow of purines and greater urinary excretion of $\mathrm{PD}$.

The digestibility of DM, OM, CP, NDFap, NFC and the TDN content presented linear decreasing behavior $(\mathrm{P}<0.05)$ with increase in DM intake, which can be related to the shorter retention time in the digestive tract, caused by the higher intake (Forbes, 1995), as well as the increase in the rate of passage of solids, thus reducing digestibility (Van Soest, 1994).

The TDN content presented decreasing linear behavior ( $\mathrm{P}<0.05$; Table 2), resulting in a decrease of $5.3 \%$ when the DM intake rose (10.0 to $21.0 \mathrm{~g} / \mathrm{kg} \mathrm{BW})$, close to the value of $5 \%$ obtained by Costa (2002) when comparing free and restricted (maintenance) supplies of dry matter intake. However, Leão et al. (2004) observed decrease of only $2 \%$ in the TDN content, when the intake level increased from 1.5 to $2.5 \mathrm{~g} / \mathrm{kg} \mathrm{BW}$, utilizing heifers of $1 / 2$ HolsteinZebu.

The mean excretion of creatinine in function of the DM intake of $25.67 \mathrm{mg} / \mathrm{kg} \mathrm{BW}$ was not altered $(\mathrm{P}>0.05)$ by the level of DM intake (Table 3). Barbosa et al. (2006) obtained average $27.1 \mathrm{mg} / \mathrm{kg} \mathrm{BW}$ for Nellore heifers, whereas Pereira (2009) observed $26.35 \mathrm{mg} / \mathrm{kg}$ BW also for Nellore animals. Rennó et al. (2000) concluded that the creatinine excretion was not affected by the addition of concentrate in the diet and presented average $27.36 \mathrm{mg} / \mathrm{kg} \mathrm{BW}$ for crossbred and zebu bulls. The value reported in this experiment lies close

Table 2 - Intake and digestibility of nutrients in function of dry matter intake levels

\begin{tabular}{|c|c|c|c|c|c|c|c|c|}
\hline & \multicolumn{4}{|c|}{ Dry matter intake (g/kg body weight) } & \multicolumn{3}{|c|}{$P$ value } & \multirow{2}{*}{$\mathrm{CV} \%$} \\
\hline & 10.0 & 13.9 & 17.5 & 21.0 & Linear & Quadratic & Cubic & \\
\hline \multicolumn{9}{|c|}{ Intake (kg/day) } \\
\hline Dry matter & 2.67 & 3.69 & 4.71 & 5.67 & $<0.0001$ & 0.5708 & 0.8664 & 3.86 \\
\hline Organic matter & 2.51 & 3.48 & 4.43 & 5.38 & $<0.0001$ & 0.1359 & 0.7738 & 3.68 \\
\hline Crude protein & 0.35 & 0.48 & 0.61 & 0.73 & $<0.0001$ & 0.6356 & 0.8873 & 4.06 \\
\hline Ether extract & 0.08 & 0.11 & 0.13 & 0.16 & $<0.0001$ & 0.7435 & 0.4676 & 4.36 \\
\hline NDFap & 1.07 & 1.48 & 1.88 & 2.28 & $<0.0001$ & 0.8028 & 0.9505 & 3.73 \\
\hline Non-fibrous carboydrates & 1.05 & 1.46 & 1.86 & 2.26 & $<0.0001$ & 0.8608 & 0.975 & 3.59 \\
\hline Total digestible nutrients & 2.10 & 2.78 & 3.51 & 4.16 & $<0.0001$ & 0.8171 & 0.6494 & 5.65 \\
\hline \multicolumn{9}{|c|}{ Digestibility (g/kg) } \\
\hline Dry matter & 771.0 & 734.0 & 731.4 & 715.6 & 0.0033 & 0.3407 & 0.3387 & 4.14 \\
\hline Organic matter & 711.2 & 680.0 & 668.7 & 625.0 & 0.0023 & 0.7102 & 0.4877 & 4.14 \\
\hline Crude protein & 775.0 & 736.2 & 728.7 & 707.5 & 0.0013 & 0.4742 & 0.4118 & 4.57 \\
\hline Ether extract & 837.5 & 838.7 & 803.7 & 806.2 & 0.0986 & 0.9700 & 0.3291 & 5.63 \\
\hline NDFap & 703.7 & 645.0 & 650.0 & 628.7 & 0.0098 & 0.2777 & 0.2454 & 7.17 \\
\hline Non-fibrous carboydrates & 888.0 & 873.5 & 856.6 & 845.9 & 0.0027 & 0.8324 & 0.8302 & 2.92 \\
\hline Total digestible nutrients $(\mathrm{g} / \mathrm{kg})$ & 786.6 & 752.4 & 745.0 & 734.2 & 0.0021 & 0.2553 & 0.5063 & 3.72 \\
\hline
\end{tabular}

$\mathrm{CV}$ - coeficient of variation; NDFap - neutral detergent fiber corrected for ash and protein. 
to that reported in the literature for animals of similar BW, although of distinct genetic groups and genders.

Mean excretions of allantoin, uric acid and total purines, absorbed purines and production of microbial nitrogen compounds (Table 3) increased linearly $(\mathrm{P}<0.05)$ with the levels of DM intake. Thus, the increase in the levels of intake resulted in greater microbial protein ruminal synthesis, a consequence of higher amounts of nutrients available in the rumen for microbial growth.

The excretion of allantoin composed approximately $89.69 \%$ of the total excretion of PD. Close ratios were obtained by Vagnoni et al. (1997) and Oliveira et al. (2001): 86.6 and $85.4 \%$, respectively. The uric acid excretion (Table 3) presented linear behavior $(\mathrm{P}<0.05)$, constituting, on average, $10.31 \%$ of the total PD excreted, values close to those found by Giesecke et al. (1994) and Silva et al. (2001), of 10.6 and $10.83 \%$, respectively.

The total excretion of purine derivatives in the urine presented increasing linear behavior $(\mathrm{P}<0.05)$ in function of the levels of DM intake, reflecting the urinary excretion of allantoin and uric acid. According to Chen \& Gomes (1992), this is due to the high activity of the enzyme xanthine oxidase present in the tissues and in the blood of bovine, which is capable of converting hypoxanthine and xanthine into uric acid before the urinary excretion.

The microbial nitrogenous compounds (MN) which were calculated from the purine derivatives excretion in the urine, for Nellore animals, according to Barbosa et al. (2011), presented increasing linear behavior in relation to the levels of DM intake.
According to Owens \& Goetsch (1986), the production of microbial $\mathrm{N}$ usually increases when there is greater DM intake; this explains the higher value of $\mathrm{MN}$ obtained when animals consumed the diet at the level of $2.10 \% \mathrm{BW}$. The average production of MN (Table 3) was $52.62 \mathrm{~g} \mathrm{~N} /$ day, approximately $10 \%$ greater than that observed by Barbosa et al. (2006), of $47.48 \mathrm{~g} \mathrm{~N} /$ day, with a diet of $25 \%$ concentrate in Nellore. Rennó et al. (2003), in a study with Zebu animals, observed average $31.29 \mathrm{~g} \mathrm{~N} /$ day in different genetic groups (Holstein; 1/2Hol-Guz; 1/2 Hol-Gir and Zebu).

Microbial efficiency was on average $106 \mathrm{~g} \mathrm{MCP} / \mathrm{kg}$ TDN, close to the value of $104 \mathrm{~g} \mathrm{MCP} / \mathrm{kg}$ TDN observed by Moraes (2003), working with Holstein $\times$ Zebu steers, receiving increasing levels of urea in the supplements $(0 ; 1.2$; $2.4 ; 3.6 \%$ on a natural matter basis). However, the NRC (2001) recommends $130 \mathrm{~g} \mathrm{MCP/kg} \mathrm{TDN} \mathrm{and} \mathrm{Pina} \mathrm{et} \mathrm{al.}$ (2010), compiling several studies utilizing animals for the production of meat and milk subjected to different feeding conditions, recommended $120 \mathrm{~g} \mathrm{MCP} / \mathrm{kg}$ TDN as reference for tropical conditions.

The $\mathrm{N}$ intake presented increasing linear behavior $(\mathrm{P}<0.05)$, following the DM intake. The urinary excretion of nitrogenous compounds was not altered $(\mathrm{P}>0.05)$ by the different levels of DM intake (Table 4). Santos et al. (2010), working with crossbred Holstein-Zebu cattle with diet containing two amounts of concentrate (1 or $2 \mathrm{~kg}$ ) and two protein sources (soybean meal or cottonseed meal) also did not observe effect of the excretion of $\mathrm{N}$ in the urine. The same behavior was obtained by Rennó et al. (2000) who, working with beef-breed steers, did not observe differences

Table 3 - Means of excretions of creatinine and purine derivatives, microbial production and efficiency obtained in function of levels of dry matter intake

\begin{tabular}{|c|c|c|c|c|c|c|c|c|}
\hline & \multicolumn{4}{|c|}{ Dry matter intake (g/kg) } & \multicolumn{3}{|c|}{$\mathrm{P}$ value } & \multirow{2}{*}{$\mathrm{CV}, \%$} \\
\hline & 10.0 & 13.9 & 17.5 & 21.0 & Linear & Quadratic & Cubic & \\
\hline Creatinine (mg/kg body weight) & 24.39 & 25.96 & 26.37 & 25.96 & 0.0670 & 0.0811 & 0.8885 & 5.83 \\
\hline Allantoin (mmol/day) & 72.48 & 77.00 & 96.73 & 97.60 & 0.0079 & 0.7977 & 0.2890 & 22.85 \\
\hline Uric acid (mmol/day) & 7.06 & 3.80 & 12.98 & 18.41 & 0.0205 & 0.2621 & 0.3471 & 99.92 \\
\hline Total purine derivatives (mmol/day) & 79.54 & 80.77 & 109.70 & 116.01 & 0.0004 & 0.7190 & 0.1245 & 20.27 \\
\hline Absorved purines (mmol/day) & 74.77 & 76.21 & 112.18 & 119.95 & 0.0005 & 0.7192 & 0.1254 & 25.52 \\
\hline Microbial nitrogen compounds (g/day) & 41.08 & 41.87 & 61.63 & 65.90 & 0.0005 & 0.7192 & 0.1253 & 25.52 \\
\hline Microbial efficiency (g/kgTDN) & 122.37 & 93.65 & 109.20 & 98.98 & 0.2215 & 0.3492 & 0.1228 & 25.53 \\
\hline
\end{tabular}

$\mathrm{CV}$ - coefficient of variation; TDN - total digestrble nutrients.

Table 4 - Means of nitrogen compounds ingested, excreted in the urine, and in the feces and nitrogen balance for the dry matter intake levels

\begin{tabular}{|c|c|c|c|c|c|c|c|c|}
\hline & \multicolumn{4}{|c|}{ Dry matter intake $(\mathrm{g} / \mathrm{kg})$} & \multicolumn{3}{|c|}{$\mathrm{P}$ value } & \multirow{2}{*}{$\mathrm{CV}, \%$} \\
\hline & 10.0 & 13.9 & 17.5 & 21.0 & Linear & Quadratic & Cubic & \\
\hline Nitrogen ingested (g/day) & 55.17 & 76.44 & 97.38 & 116.92 & $<0.0001$ & 0.4949 & 0.8487 & 4.03 \\
\hline Nitrogen excretec in the urine ( $\mathrm{g} /$ day) & 44.34 & 46.5 & 48.79 & 49.12 & 0.1165 & 0.6878 & 0.8388 & 13.39 \\
\hline Nitrogen excreted in the feces (g/day) & 12.48 & 20.35 & 26.55 & 34.38 & $<0.0001$ & 0.9899 & 0.4797 & 12.27 \\
\hline Nitrogen balance (g/day) & -1.64 & 9.59 & 22.05 & 33.42 & $<0.0001$ & 0.9736 & 0.7979 & 35.12 \\
\hline
\end{tabular}

CV - coefficient of variation. 
in the excretions of $\mathrm{N}$ in the urine between the types of concentrates. However, Dias et al. (2000) verified linear increase in the $\mathrm{N}$ urinary excretion with increase in the concentrate levels. In accordance with several authors, Van Soest (1994) described the increase of urinary excretion of nitrogenous compounds in function of the intake of DM and $\mathrm{CP}$ in the diet.

The fecal $\mathrm{N}$ excretion (Table 4) presented increasing linear behavior $(\mathrm{P}<0.05)$ in function of increase in the $\mathrm{DM}$ intake. According to Véras et al. (2007), Nellore cattle fed diets based on corn silage and concentrate at the 75 and $25 \%$ ratios on a DM basis balanced to contain $7,10,13$ and $15 \% \mathrm{CP}$ presented increasing linear behavior for the excretion of fecal N (35.97 to $46.99 \mathrm{~g} /$ day).

The $\mathrm{N}$ balance increased linearly $(\mathrm{P}<0.05)$ with increase in the DM intake (Table 4). Valadares et al. (1997b) obtained linear relation between $\mathrm{N}$ balance, expressed in $\mathrm{g} /$ day, and the $\mathrm{CP}$ content of diets.

It is worth stressing that negative $\mathrm{N}$ balance was verified at $1 \% \mathrm{DM}$ intake, which was a similar behavior to the observed by Dias et al. (2000), working with crossbred F1 Limousin $\times$ Nellore cattle with diet of 25 and 37.5\% concentrate. The negative $\mathrm{N}$ balance means that the level of $\mathrm{CP}$ intake was not enough to meet the maintenance requirements of these animals.

The excretion of purine derivatives expressed in $\mathrm{mmol} /$ day (Table 3) increased linearly with the intake levels of DM in the diet. Thus, when it was evaluated in function of digestible OM intake, the simple linear regression (Figure 1) was obtained, in which the excretion of $\hat{Y}=$ $32.98+21.94 x$. Mo et al. (2004), working with $B$. indicus and B. namadicus steers, with diet supplied at 40 and $95 \%$ of voluntary intake, found regression $\hat{Y}=18.9$ $+21.4 \mathrm{x}\left(\mathrm{r}^{2}=0.97\right)$. Barbosa et al. (2011), working with Nellore heifers, observed linear ratio of urinary excretion of PD in function of digestible OM intake: $\hat{Y}=0.59+34.4 x$ $\left(r^{2}=0.74\right)$. Relating the same variable to Nellore heifers and utilizing a diet containing 60\% roughage, Pereira (2009) observed regression $\hat{Y}=14.57+35.10 x\left(r^{2}=0.78\right)$.

When the excretion of purine derivatives ( $\mathrm{mmol} /$ day) was related to TDN intake (kg/day, Figure 2), the following equation was observed: $\hat{\mathrm{Y}}=32.47+20.40 \mathrm{x}\left(\mathrm{r}^{2}=0.44\right)$, which resulted in excretion of $20.40 \mathrm{mmol} \mathrm{PD} / \mathrm{kg}$ TDN consumed, which is an inferior value to the one obtained by Barbosa et al. (2011), which was $32.15 \mathrm{mmol} / \mathrm{kg}$ TDN.

When the excretion of purine derivatives ( $\mathrm{mmol} / \mathrm{kg} \mathrm{BW}^{0.75}$ ) was related to DM intake expressed in $\mathrm{g} / \mathrm{kg} \mathrm{BW}{ }^{0.75}$ (Figure 3), the following equation was obtained: $\hat{Y}=0.605$ $+0.014 \mathrm{X}\left(\mathrm{r}^{2}=0.46\right.$, in which the value of the intercept of
$0.605 \mathrm{mmol} / \mathrm{kg} \mathrm{BW}^{0.75}$ stands for the endogenous fraction of PD excreted in the urine. In surgically intact animals, the endogenous excretion of PD is difficult to evaluate, due to limitations to eliminate the contribution of rumen

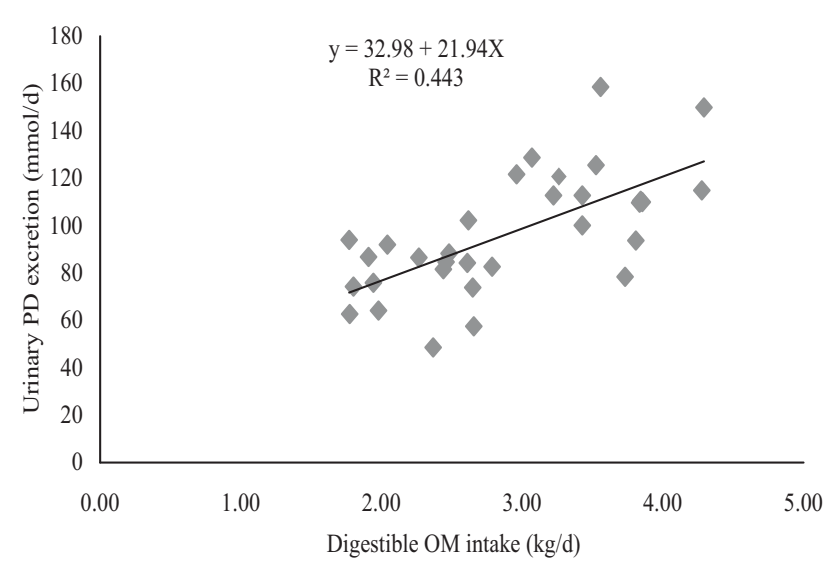

Figure 1 - Relation between urinary purine derivative (PD) excretion and digestible organic matter (OM) intake.

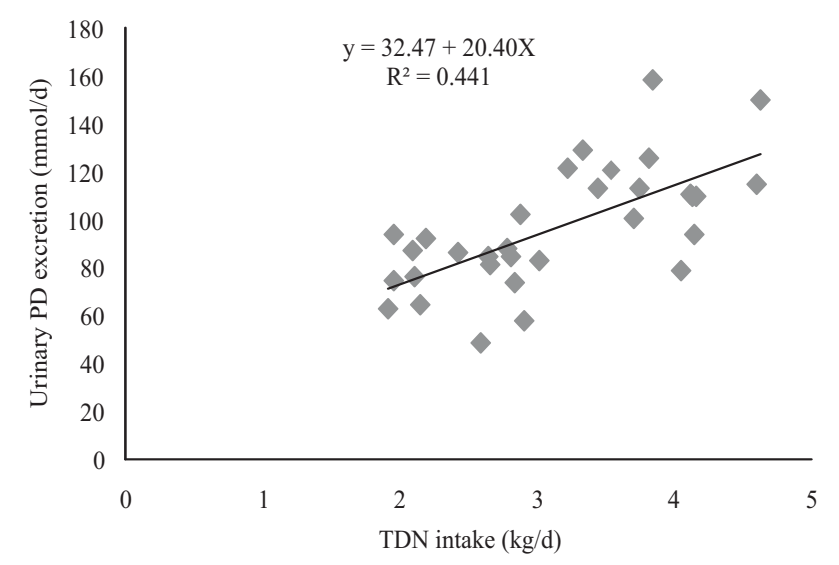

Figure 2 - Relation between urinary purine derivative (PD) excretion and total digestible nutrients (TDN) intake.

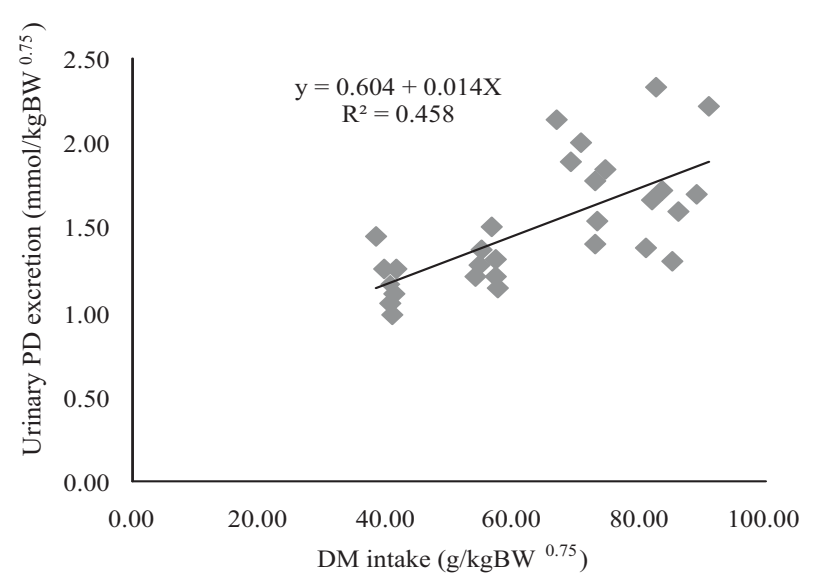

BW - body weight.

Figure 3 - Relation between urinary purine derivative (PD) excretion and dry matter (DM) intake. 
microorganisms under normal physiological conditions in rumminants (Fujihara et al., 1987; Chen et al., 1990).

The relation between fecal $\mathrm{N}$ excretion and $\mathrm{N}$ intake, expressed in $\mathrm{g} / \mathrm{kg} \mathrm{BW}^{0.75}$, was described by the equation: $\hat{\mathrm{Y}}=0.350 \mathrm{x}-0.104\left(\mathrm{r}^{2}=0.86\right)$, allowing the estimate of fecal metabolic nitrogen at $0.104 \mathrm{~g} / \mathrm{kg} \mathrm{BW}^{0.75}$ (Figure 4).

From the results of the period in which animals were subjected to fasting, it could be observed that the excretion of purine derivatives on the fourth day was of $0.381 \mathrm{mmol} /$ $\mathrm{kg} \mathrm{BW}^{0.75}$, and on the fifth day, it was $0.283 \mathrm{mmol} / \mathrm{kg} \mathrm{BW}^{0.75}$; an average of $0.332 \pm 0.069 \mathrm{mmol} / \mathrm{kg} \mathrm{BW}^{0.75}$ was considered. According to Balcells et al. (1991), the excretion of PD at fasting can be considered an approximate estimate of the endogenous contribution to the urinary excretion, although there is no experimental evidence of a complete absence of purine derivatives from exogenous origin, during feed restriction. Bos indicus $\times$ Bos taurus animals, subjected to 5 days of fasting, presented values of $0.277 \mathrm{mmol} / \mathrm{kg}$ $\mathrm{BW}^{0.75}$ endogenous excretion of PD (Ojeda et al., 2005) and $0.170 \mathrm{mmol} / \mathrm{kg} \mathrm{BW}{ }^{0.75}$ was observed by Osuji et al. (1996), working with Bos indicus also kept at fasting. Chen \& Orskov (2003) criticized the method of prolonged fasting because it altered the metabolic activities of the animal, and hence the degradation rate of nucleic acids. However, Barbosa et al. (2011) suggested endogenous excretion of $\mathrm{PD}$ of $0.300 \mathrm{mmol} / \mathrm{kg} \mathrm{BW}^{0.75}$, which is $9.6 \%$ lower than the mean value obtained in this experiment.

There are several records demonstrating that the excretion of creatinine consists of a constant function of animal live weight (Orskov \& Mcleod, 1982; Susmel et al., 1994; Vagnoni et al., 1997; Valadares et al., 1997a; Valadares et al., 1999; Rennó et al., 2000) and is not affected by the different intake levels (Oliveira et al., 2001). The relation between creatinine excretion and the period in which animals were subjected to fasting did not result in significant regression $(\mathrm{P}>0.05)$, resulting in mean daily value of $0.211 \mathrm{mmol} / \mathrm{kg} \mathrm{BW}^{0.75}$, representing the excretion of creatinine in the fasting period. Thus, one can say that the excretion of creatinine was not altered by fasting; the same behavior was observed by Belenguer et al. (2002), who found $0.266 \mathrm{mmol} / \mathrm{kg} \mathrm{BW} \mathrm{BW}^{0.75}$ when subjecting sheep to fasting for 6 days.

The regression between retained $\mathrm{N}$ and $\mathrm{N}$ intake, expressed in $\mathrm{g}$ of $\mathrm{N} / \mathrm{kg} \mathrm{BW} \mathrm{BW}^{0.75}$ was described by the equation, in which 0.486 accounts for the endogenous $\mathrm{N}$ fraction, expressed in $\mathrm{N} / \mathrm{kg} \mathrm{BW}^{0.75}$ or $3.04 \mathrm{~g} \mathrm{CP} / \mathrm{kg} \mathrm{BW}^{0.75}$ (Figure 5). Véras et al. (2007), working with Zebu animals of the Nellore breed and using four levels of crude protein (7, 10,13 and $15 \%$ ) in the diets, observed $0.431 \mathrm{~N} / \mathrm{kg} \mathrm{BW}^{0.75}$ for endogenous $\mathrm{N}$, or $2.69 \mathrm{~g} \mathrm{CP} / \mathrm{kg} \mathrm{BW}^{0.75}$. Tibo et al. (2000),

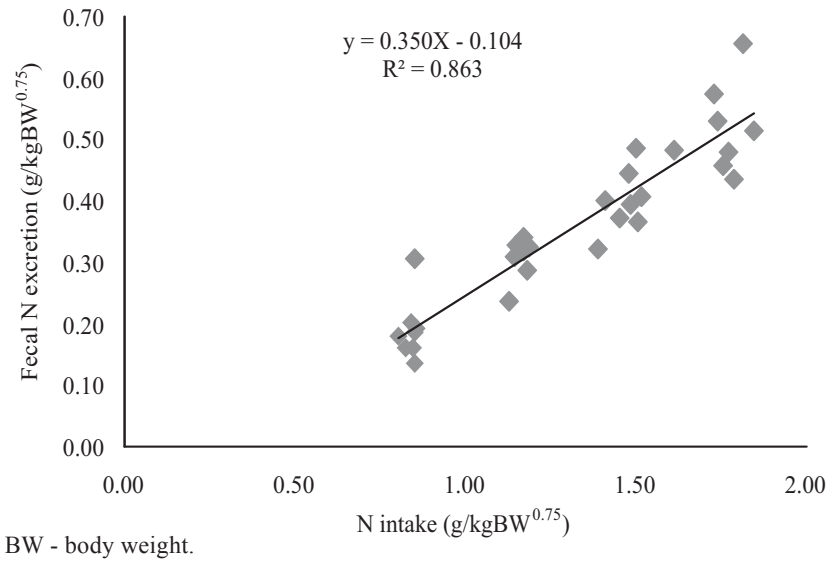

Figure 4 - Relation between fecal $\mathrm{N}$ excretion and $\mathrm{N}$ intake.

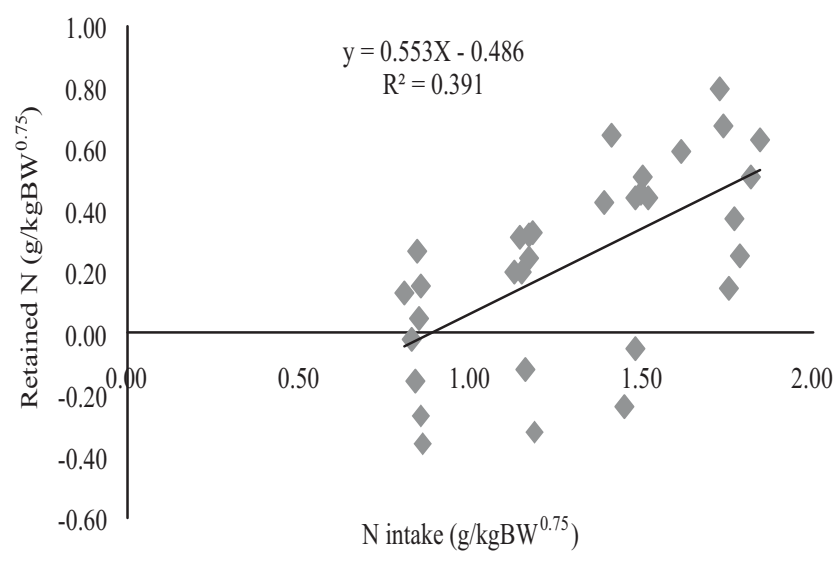

BW - body weight.

Figure 5 - Relation between retained $\mathrm{N}$ and $\mathrm{N}$ intake $\left(\mathrm{g} / \mathrm{kg} \mathrm{BW}^{0.75}\right)$.

working with crossbred F1 Simental x Nellore animals, obtained, by regression, the value of $0.422 \mathrm{~g} \mathrm{~N} / \mathrm{kg} \mathrm{BW}^{0.75}$ for endogenous $\mathrm{N}$ losses. These values were superior to those cited by the AFRC (1993), of $2.3 \mathrm{~g} \mathrm{CP} / \mathrm{kg} \mathrm{BW}^{0.75}$ and by Valadares et al. (1997b), of $0.246 \mathrm{~g} \mathrm{~N} / \mathrm{kg} \mathrm{BW}^{0.75}$.

\section{Conclusions}

The total digestible nutrient content is reduced in approximately $5 \%$ when the intake goes from restricted to voluntary. There is a linear relation between urinary excretion of purine derivatives and dry matter intake, and this excretion can be estimated from the intake of total digestible nutrients and digestible organic matter. In animals subjected to fasting, the excretion of creatinine is not altered and the excretions of purine derivatives and nitrogenous compounds allow the estimation of the endogenous contribution of $0.332 \pm 0.063 \mathrm{mmol} / \mathrm{kg} \mathrm{BW}{ }^{0.75}$ and $0.384 \mathrm{~g} \mathrm{~N} / \mathrm{kg} \mathrm{BW}^{0.75}$, respectively. 


\section{References}

AGRICULTURAL AND FOOD RESEARCH COUNCIL - AFRC. Energy and protein requirements of ruminants. Wallingford, UK: CAB International, 1993. 159p.

BALCELlS, J.; GUADA, J.A.; CASTRILlO, C. et al. Urinary excretion of allantoin precursors by sheep after differents rates of purine infusion into the duodenum. Journal Agriculture Science (Camb), v.116, p.309-317, 1991.

BARBOSA, A.M.; VALADARES, R.F.D.; VALADARES FILHO, S.C. et al. Efeito do período de coleta de urina, dos níveis de concentrado e de fontes protéicas sobre a excreção de creatinina, de uréia e de derivados de purina e a produção microbiana em bovinos Nelore. Revista Brasileira de Zootecnia, v.35, n.3, p.870-877, 2006.

BARBOSA, A.M.; VALADARES, R.F.D.; VALADARES FILHO, S.C. et al. Endogenous fraction and urinary recovery of purine derivatives obtained by different methods in Nellore cattle, Journal Animal Science, v.89, p.510-519, 2011

BELENGUER, A.; YAÑEZ, D.; BALCELLS, J. et al. Urinary excretion of purine derivates and prediction of rumen microbial outflow in goats. Livestock Production Science, v.77, p.127-135, 2002.

BRODERICK, G.A.; MERCHEN, N.R. Markers for quantifying microbial protein synthesis in the rumen. Journal of Dairy Science, v.75, p.2618-2632, 1992.

CHEN, X.B.; MATHIESON, F.D.D.H.; REEDS, P.J. Measurements of purine derivatives in urine of ruminants using automated methods. Journal Agriculture Science, v.53, p.23-33, 1990.

CHEN, X.B.; GOMES, M.J. Estimation of microbial protein supply to sheep and cattle based on urinary excretion of purine derivatives - an overview of technical details. Aberdeen: Rowett Research Institute/International Feed Research Unit, 1992. 21p. (Occasional Publication).

CHEN, X.B.; ØRSKOV, E.R. Research on urinary excretion of purine derivatives in ruminants: Past, present and future. Aberdeen, UK: International Feed Resources Unit, Macaulay Land Use Research Institute, Craigiebuckler, 2003. 34p.

COSTA, M.A.L. Desempenho de novilhos zebuínos e validação das equações do NRC (2001) para predizer o valor energético dos alimentos nas condições brasileiras. 2002. 80f. Dissertação (Mestrado em Zootecnia) - Universidade Federal de Viçosa, Viçosa, MG.

DIAS, H.L.C.; VALADARES FILHO, S.C.; COELHO DA SILVA, J.F. et al. Consumo e digestões totais e parciais em novilhos F1 Limousin $\mathrm{x}$ Nelore alimentados com dietas contendo cinco níveis de concentrado. Revista Brasileira de Zootecnia, v.29, n.2, p.545-554, 2000.

FORBES, J.M. Voluntary food intake and diet selection in farm animals. Wallingford: CAB International, 1995. 532p.

FUJIHARA, T.; ORSKOV, E.R.; REEDS, P.J. et al. The effect of protein infusion on urinary excretion of purine derivatives in ruminants nourished by intragastric nutrition. Journal of Agricultural Science, v.109, n.1, p.7-12, 1987.

GIESECKE，D.; EHRENTREICH， L.; STANGASSINGER, M. Mammary and renal excretion of purine metabolites in relation to energy intake and milk yield in dairy cows. Journal of Dairy Science, v.77, n.8, p.2376-2381, 1994.

GONZALEZ RONQUILLO, M.; BALCELLS, J.; GUADA, J.A. et al. Purine derivative excretion in dairy cows: Endogenous excretion and the effect of exogenous nucleic acid supply. Journal of Dairy Science, v.86, n.4, p.1282-1291, 2003.

LEÃO, M.I.; VALADARES FILHO, S.C.; RENNÓ, L.N. et al. Consumos e digestibilidades totais e parciais de matéria seca, matéria orgânica, proteína bruta e extrato etéreo em novilhos submetidos a três níveis de ingestão e duas metodologias de coleta de digestas abomasal e omasal. Revista Brasileira de Zootecnia, v.33, n.6, p.1604-1615, 2004
LICITRA, G.; HERNANDES, T.M.; Van SOEST, P.J. Standardization of procedures for nitrogen fractionation of ruminant feeds. Animal Feed Science and Technology, v.57, p.347-358, 1996.

MERTENS, D.R. Gravimetric determination of amylase-treated neutral detergent fiber in feeds with refluxing in beakers or crucibles: collaborative study. Journal of AOAC International, v.85, p.1217-1240, 2002.

MO, F.; WANG, Y.X.; XING, Z. et al. The effect of different levels of feed intake on the urinary excretion of purine derivatives in Chinese yellow cattle. MAKKAR, H.P.S.; CHEN, X.B. (Eds.) In: Estimation of microbial protein supply in ruminants using purine derivatives. Dordrecht: Kluwer Academic Publishers, 2004. p. 103-108

MORAES, E.H.B.K. Suplementos múltiplos para recria e terminação de novilhos mestiços em pastejo durante os períodos de seca e transição seca-águas. 2003, 69f. Dissertação (Mestrado em Zootecnia) - Universidade Federal de Viçosa, Viçosa, MG.

NATIONAL RESEARCH COUNCIL - NRC. Nutrient requirements of dairy cattle. 7.ed. Washington, D.C.: National Academy Press, 2001. 381p.

OJEDA, A.; PARRA, O.; BACELLS, J. et al. Urinary excretion of purine in Bos indicus x Bos taurus crossbred cattle. British Journal of Nutrition, v.93, p.821-828, 2005.

OLIVEIRA, A.S.; VALADARES, R.F.D.; VALADARES FILHO, S.C. et al. Produção de proteína microbiana e estimativas das excreções de derivados de purinas e de uréia em vacas lactantes alimentadas com rações isoproteicas contendo diferentes níveis de compostos nitrogenados não-protéicos, Revista Brasileira de Zootecnia, v.30, n.5, p.1621-1629, 2001.

ORELLANA BOERO, P.; BALCELLS, J.; MARTÍN-ORÚE, S.M. et al. Excretion of derivatives in cows: endogenous contribution and recovery of exogenous purine bases. Livestock Production Science, v.68, p.243-250, 2001.

ØRSKOV, E.R.; MACLEOD, N.A. The determination of the minimal nitrogen excretion in steers and dairy cows and its physiological and practical implications. British Journal of Nutrition, v.47, p.625-636, 1982.

OSUJI, P.O.; NSAHLAI, I.V.; KHALILI, H. Effect of fasting on the urinary excretion of nitrogen and purine derivatives by zebu (Bos indicus) and crossbred (Bos indicus $\mathrm{x}$ Bos taurus) cattle. Journal of Applied Animal Research, v.10, p.39-47, 1996.

OWENS, F.N.; GOETSCH, A.L. Digest passage and microbial protein synthesis. In: MILLIGAN, L.P.; GROVUM, W.L.; DOBSON, A. (Eds.). Control of digestion and metabolism in ruminants. New Jersey: Prentice Hall, 1986. p.196-226.

PEREIRA, V.S.A. Influência do peso corporal e das características de carcaça sobre a excreção de creatinina e utilização de coleta spot de urina para estimar a excreção de derivados de purina e de compostos nitrogenados em novilhas Nelore. 2009. $55 \mathrm{f}$. Tese (Mestrado em Medicina Veterinária) - Universidade Federal de Viçosa, Viçosa, MG.

PINA, D.S.; VALADARES, R.F.D.; VALADARES FILHO, S.C. et al. Degradação ruminal da proteína dos alimentos e síntese de proteína microbiana. Exigências nutricionais de zebuínos puros e cruzados (BR CORTE). 2.ed. Viçosa, MG: UFV, 2010. p.13-46.

RENNÓ, L.N.; VALADARES FILHO, S.C.; VALADARES, R.F.D. et al. Níveis de proteína na ração de novilhos de quatro grupos genéticos: estimativa da produção de proteína microbiana por intermédio dos derivados de purinas na urina. In: REUNIÃO ANUAL DA SOCIEDADE BRASILEIRA DE ZOOTECNIA, 40., 2003 Santa Maria. Anais... Santa Maria: 2003. (CD-ROM).

RENNÓ, L.N.; VALADARES, R.F.D.; VALADARES FILHO, S.C. et al. Concentração plasmática de uréia e excreções de uréia e creatinina em novilhos. Revista Brasileira de Zootecnia, v.29, p.1235-1243, 2000.

SANTOS, S.A.; CAMPOS, J.M.S.; VALADARES FILHO, S.C. et al. Balanço de nitrogênio em fềmeas leiteiras em confinamento alimentadas com concentrado à base de farelo de algodão. Revista Brasileira de Zootecnia, v.39, n.5, p.1135-1140, 2010. 
SILVA, D.J.; QUEIROZ, A.C. Análise de alimentos - métodos químicos e biológicos. 3.ed. Viçosa, MG: Editora UFV, 2002. $235 \mathrm{p}$.

SILVA, R.M.N.; VALADARES, R.F.D.; VALADARES FILHO, S.C. et al. Uréia para vacas em lactação. 2. Estimativas do volume urinário, da produção microbiana e da excreção de uréia. Revista Brasileira de Zootecnia, v.30, n.6, p.1948-1957, 2001.

SUSMEL, P.; STEFANON, B.; PLAZZOTA, E. et al. The effect of energy and protein intake on the excretion of purine derivatives. Journal of Agricultural Science, v.123, p.257-266, 1994.

TIBO, G.C.; VALADARES FILHO, S.C.; COELHO DA SILVA, J.F. et al. Níveis de concentrado em dietas de novilhos F1 Simental x Nelore: 1 - Consumo e digestibilidades. Revista Brasileira de Zootecnia, v.29, n.5, p.921-929, 2000.

VAGNONI, D.B.; BRODERICK, G.A.; MERCHEN, N.R. et al. Excretion of purine derivatives by Holstein cows abomasally infused with incremental amounts of purines. Journal of Dairy Science, v.80, p.1695-1702, 1997.

VALADARES, R.F.D.; BRODERICK, G.A.; VALADARES FILHO, S.C. et al. Effect of replacing alfafa with high moisture corn on ruminal protein synthesis estimated from excretion of total purine derivatives. Journal of Dairy Science, v.82, p.2686-2696, 1999.

VALADARES, R.F.D.; GONÇALVES, L.C.; VALADARES FILHO, S.C. et al. Níveis de proteína em dietas de bovino. 4. Concentrações de amônia ruminal e uréia plasmática e excreções de uréia e creatinina. Revista Brasileira de Zootecnia, v.26, n.6, p.1270-1278, 1997a.

VALADARES, R.F.D.; GONÇALVES, L.C.; RODRIGUEZ, N.M. et al. Metodologia de coleta de urina em vacas utilizando sondas de Folley. Revista Brasileira de Zootecnia, v.26, n.6, p.1279-1282, 1997 b.

VAN SOEST, P.J. Nutritional ecology of the ruminant. 2.ed. London: Constock Publishing Associates, 1994. 476p.

VÉRAS, R.M.L.; VALADARES FILHO, S.C.; VALADARES, R.F.D. et al. Balanço de compostos nitrogenados e estimativa das exigências de proteína de mantença de bovinos Nelore de três condições sexuais. Revista Brasileira de Zootecnia, v.36, n.4, p.1212-1217, 2007 (supl.).

VERBIC, J.; CHEN, X.B.; MACLEOD, N.A. et al. Excretion of purine derivatives by ruminants. Effect of microbial nucleic acid infusion on purine derivatives excretion by steers. Journal Agriculture Science, v.114, n.3, p.243-248, 1990. 